\title{
ANALISIS IM PLEMENTASI KURIKULUM 2013 DI SMA NEGERI 3 REJANG LEBONG, BENGKULU
}

\author{
Gita Y olanda, \\ Institut A gama Islam N egeri Curup, B engkulu \\ gitayolanda09091999@gmail.com \\ Saidil M ustar \\ Institut A gama Islam N egeri Curup, B engkulu \\ Deri Wanto \\ Institut A gama Islam N egeri Curup, B engkulu
}

\begin{abstract}
This study aimed at analyzing qualitatively the implementation of $K 13$ curriculum which has long been applied in the state senior high school number 3 of Rejang Lebong. The data were garnered using observations and interviews for the sake of eliciting information to answer the proposed problem. The other technique considered important was documentation to see the curriculum-based depictions and loads in the existing documents. After the data were gathered, the selection of data was undertaken in order to be displayed in findings; the data were analyzed and discussed; and they were concluded as the ultimate answer to the formulated problem. The present study drew a conclusion that the implementation of $k 13$ curriculum ran well although some obstacles were faced such as learning facilities. The entire school's community seemed to be committed to carry out the mandate of this national educational system's law such as training for teachers' competence, doing the duties of making lesson plans in the form of RPP and syllabi, providing a monthly report concerning the implementation of learning by teachers, and carrying out evaluations alongside giving guidance for teachers' performances.
\end{abstract}

Keywords; implementation, K-13 curriculum, learning quality 


\begin{abstract}
A bsrak
Penelitian ini bertujuan untuk melakukan analisis terhadap pelaksanaan kurikulum 2013 yang telah lama diterapkan di SMA Negeri 3 Rejang Lebong melalui pendekatan kualitatif. Data dikumpulkan melalui observasi dan wawancara untuk menemukan informasi yang tepat untuk menjawab penelitian ini. Teknik lain yang tidak kalah penting adalah dokumentasi untuk melihat gambaran data muatan kurikulum pada dokumen. Setelah data terkumpul dilakukan pemilihan data untuk disajikan dalam hasil penelitian dan dianalisis dalam pembahasan selanjutnya diperoleh simpulan sebagai jawaban permasalahan yang telah dirumuskan. Penelitian ini memperoleh simpulan bahwa pelaksanaan K-13 berjalan dengan baik meskipun ditemui kendala seperti fasilitas pembelajaran, terlihat pada komitmen seluruh perangkat sekolah melaksanakan amanah undangundang sistem pendidikan nasional tersebut dengan berbagai strategi dan kemampuan yang dimiliki oleh sekolah, seperti pelatihan kompetensi guru, melaksanakan kewajiban membuat perencanaan pembelajaran dalam bentuk RPP dan silabus, memberikan laporan bulanan tentang pelaksanaan pembelajaran oleh guru dan melakukan evaluasi serta pembinaan terhadap kinerja guru.
\end{abstract}

K ata K unci: Implementasi, K urikulum 2013, K ualitas Pemberajara

\title{
PENDAHULUAN
}

K urikulum secara etimologis berasal dari bahasa Latin yaitu curir yang berarti pelari dan curere yang berarti tempat berlari ${ }^{1}$. Dalam sejarahnya, kurikulum merupakan suatu jarak yang harus ditempuh oleh pelari muali dari garis awal atau start sampai dengan finish2. Jika kurikulum dikaitkan dengan dunia pendidikan dapat diartikan sebagai rencana dan pengaturan

\footnotetext{
Zainul Arifin, Saida Ulfa, and Henry Praherdhiono, "Pengembangan Kurikulum Muatan Lokal Karawitan Sebagai Upaya Mengkonstruksi Pengetahuan Dan Pelestarian Budaya Jawa Di Jenjang SMA," Jurnal Kajian Teknologi Pendidikan 1, no. 2 (2018): 123-132; Muhammad Fadlillah, "Model Kurikulum Pendidikan Multikultural Di Taman Kanak-Kanak," Jurnal Pembangunan Pendidikan: Fondasi Dan Aplikasi 5, no. 1 (2017): 42-51; Fawaz Fawaz, "Filsafat Pendidikan Islam, Tinjauan Filosofis Tentang Kurikulum," Jurnal Al-Irfani: Jurnal Kajian Tafsir Hadits 5, no. 2 (2019): 1-14; Ibrahim Nasbi, "Manajemen Kurikulum: Sebuah Kajian Teoritis," Idaarah: Jurnal Manajemen Pendidikan 1, no. 2 (2017).

2 Fakhrul Rijal, "Guru Profesional Dalam Konsep Kurikulum 2013," Jurnal Mudarrisuna: Media Kajian Pendidikan Agama Islam 8, no. 2 (2018): $328-346$.
} 
tentang sejumlah mata pelajaran yang harus dipelajari peserta didik dalam menempuh pendidikan di lembaga pendidikan³. Sementara dalam bahasa Arab, kata kurikulum biasa diungkapkan dengan manhaj yang berarti jalan yang dilalui oleh manusia pada berbagai bidang kehidupan. Sedangkan kurikulum pendidikan (manhaj al-dirasah) dalam kamus tarbiyah adalah seperangkat perencanaan dan media yang dijadikan acuan oleh lembaga pendidikan dalam mewujudkan tujuan-tujuan pendidikan 4 .

Jika ditinjau dari perspektif UU Nomor 20 Tahun 2003 pasal 1 butir 19: "K urikulum adalah seperangkat rencana dan pengaturan mengenai tujuan, isi, dan bahan pelajaran serta cara yang digunakan sebagai pedoman penyelenggaraan kegiatan pembelajaran untuk mencapai tujuan pendidikan tertentu" ${ }^{5}$. Kurikulum merupakan gagasan pendidikan yang diekspresikan dalam praktik atau dapat disebut sebagai seperangkat rencana yang memuat yang memuat tujuan yang ingin dicapai dalam pendidikan sesuai dengan tingkat dan jenjangnya dan berisi bahan pelajaran dan metode yang digunakan sebagaia acuan bagi sekolah untuk selanjutmya dilaksanakan dengan agar tercapai tujuan yang telah ditetapkan dalam kurikulum tersebut.

Istilah kurikulum tersebut digunakan dalam dunia pendidikan dengan alasan berhubungan erat dengan usaha mengembangkan peserta didik sesuai dengan tujuan yang ingin

3 Ishak Talibo, "Fungsi Manajemen Dalam Perencanaan Pembelajaran," Jurnal Ilmiah Iqra' 7, no. 1 (2018); Fadlillah, "Model Kurikulum Pendidikan Multikultural Di Taman Kanak-Kanak.”

4 Muhammad Roihan Alhaddad, "Hakikat Kurikulum Pendidikan Islam," Raudhah Proud To Be Professionals: Jurnal Tarbiyah Islamiyah 3, no. 1 (2018): 57-66.

5 Andi Prastowo, Menyusun Rencana Pelaksanaan Pembelajaran (RPP) Tematik Terpadu: Implementasi Kurikulum 2018 Untuk SD/MI (Kencana, 2017); Afni Ma'rufah, "Implementasi Kurikulum Mata Pelajaran Pendidikan Agama Islam (Upaya Mewujudkan Budaya Religius Di Sekolah)," Edukasia: Jurnal Pendidikan Dan Pembelajaran 1, no. 1 (2020): 125-136; Uun Lionar and Agus Mulyana, "Nilai-Nilai Multikultural Dalam Pembelajaran Sejarah: Identifikasi Pada Silabus," Indonesian Journal of Social Science Education (IJSSE) 1, no. 1 (2019): 11-25. 
dicapai. Sehingga kurikulum memiliki beberapa aspek penting seperti perencanaan pengalaman belajar, program sebuah lembaga pendidikan yang diwujudkan dalam sebuah dokumen serta hasil dari implementasi dokumen yang telah disusun.

Kurikulum 2013 merupakan implementasi dari UU no. 32 tahun 2013 dan kelanjutan serta penyempurna dari kurikulum berbasis kompetensi (K BK) dan KTSP, akan tetapi lebih mengacu pada kompetensi sikap, pengetahuan dan keterampilan secara terpadu'. A manat UU 20 tahun 2003 tentang Sistem Pendidikan Nasional yang terdapat pada pasal 35, menyatakan bahwa "kompetensi lulusan merupakan kualifikasi kemampuan lulusan yang mencakup sikap, pengetahuan, dan keterampilan sesuai dengan standar nasional yang telah disepakati"7. Paparan ini merupakan bagian dari uji publik kurikulum 2013 yang diharapkan dapat menjaring pendapat dan masukan dari masyarakat secara positif. Jadi dapat diambil kesimpulan bahwa kurikulum adalah sesuatu yang direncanakan untuk dipelajari siswa yang sudah terstruktur dalam suatu bidang studi dalam suatu pembelajaran agar tercapainya tujuan yang diharapkan.

Selain itu kurikulum sebagai suatu substansi yang dipandang orang sebagai rencana kegiatan belajar bagi muridmurid di sekolah, atau sebagai suatu perangkat tujuan yang ingin dicapai. Kurikulum juga dapat menunjuk kepada suatu dokumen yang berisi rumusan tentang tujuan, bahan ajar, kegiatan belajar-mengajar, jadwal, dan evaluasi. Artinya,

6 Indah Sari Irmadani, "Implementasi Kurikulum 2013 Mata Pelajaran Pendidikan Agama Islam Di SD Swasta (Studi Kasus Pada Sekolah Dasar Swasta Islam Terpadu Permata Cendekia)," Ansiru Pai: Pengembangan Profesi Guru Pendidikan Agama Islam 3, no. 1 (2019): 4661; Syahabuddin Nur, "Peran dan Kontribusi Penerjemahan pada Mata Pelajaran Bahasa Arab Tingkat Madrasah Aliyah," Al Mi'yar: Jurnal Ilmiah Pembelajaran Bahasa Arab Dan Kebahasaaraban 2, no. 1 (2019): 105-126.

7 Syaiful Islam, "Karakteristik Pendidikan Karakter; Menjawab Tantangan Multidimensional Melalui Implementasi Kurikulum 2013," Edureligia: Jurnal Pendidikan Agama Islam 1, no. 1 (2017): 89-100; Neneng Sunengsih, "Analisis Kebijakan Standar Kompetensi Lulusan Dan Standar Isi Pendidikan Agama Islam Dalam Kurikulum Nasional," Al Ulya: Jurnal Pendidikan Islam 5, no. 1 (2020): https-doi. 
kurikulum juga dapat digambarkan sebagai dokumen tertulis sebagai hasil persetujuan bersama antara para penyusun kurikulum dan pemegang kebijaksanaan pendidikan dengan masyarakat. Suatu kurikulum juga dapat mencakup lingkup tertentu, suatu sekolah, suatu kabupaten, propinsi, ataupun seluruh negara.

Sejarah kurikulum pendidikan di Indonesia kerap berubah setiap ada pergantian Menteri Pendidikan, sehingga mutu pendidikan Indonesia hingga kini belum memenuhi standar mutu yang jelas dan mantap. Dalam perjalanan sejarah sejak tahun 1945, kurikulum pendidikan nasional telah mengalami perubahan, yaitu pada tahun 1947, 1952, 1964, 1968, 1975, 1984, 1994, 2004, 2006 dan 20138. Perubahan tersebut merupakan konsekuensi logis dari terjadinya perubahan sistem politik, sosial budaya, ekonomi, dan iptek dalam masyarakat berbangsa dan bernegara. Sebab, kurikulum sebagai seperangkat rencana pendidikan perlu dikembangkan secara dinamis sesuai dengan tuntutan dan perubahan yang terjadi di masyarakat. Semua kurikulum nasional dirancang berdasarkan landasan yang sama, yaitu Pancasila dan UUD 1945, perbedaanya pada penekanan pokok dari tujuan pendidikan serta pendekatan dalam merealisasikannya.

Salah satu kurikulum baru yang digunakan saat ini adalah kurikulum 2013. K urikulum 2013 merupakan kurikulum terbaru yang diluncurkan oleh K ementrian Pendidikan Nasional mulai tahun 2013 sebagai bentuk pengembangan dari kurikulum sebelumnya yaitu kurikulum 2006 atau Kurikulum Tingkat Satuan Pendidikan (KTSP) yang mencangkup kompetensi sikap, pengetahuan, dan keterampilan secara terpadu. Hal ini senada dengan apa yag ditegaskan dalam pasal 1 ayat 29 Undang-Undang no. 20 tahun 2003 bahwa "kurikulum merupakan pengaturan mengenai tujuan, isi, dan bahan pelajaran serta cara yang digunakan sebagai pedoman

8 Moch Yasykur, "Implementasi Kurikulum 2013 Di Madrasah Aliayah Ibnu Taimiyah Bogor," Edukasi Islami: Jurnal Pendidikan Islam 3, no. 05 (2017); Widiatmoko Herbimo, "Kurikulum Bukan Senjata Pamungkas Keberhasilan Pendidikan,” Jurnal Ilmiah WUNY 18, no. 2 (2016). 
penyelenggara kegiatan pembelajaran untuk mencapai tujuan pendidikan tertentu" 9 .

Kurikulum 2013 diberlakukan secara bertahap mulai tahun ajaran 2013-2014 melalui pelaksanaan terbatas, khususnya bagi sekolah-sekolah yang sudah siap melaksanakannya. Pada Tahun Ajaran 2013/2014, Kurikulum 13 dilaksanakan secara terbatas untuk K elas I dan IV Sekolah Dasar/M adrasah Ibtidaiyah (SD/MI), Kelas VII Sekolah Menengah Pertama/M adrasah Tsanawiyah (SMP/MTs), dan Kelas $X$ Sekolah Menengah Atas/Sekolah Menengah Kejuruan/M adrasah Aliyah (SMA/SMK/MA/MAK). Pada Tahun Ajaran 2015/2016 diharapkan Kurikulum 2013 telah dilaksanakan di seluruh kelas I sampai dengan K elas X II ${ }^{10}$.

M embahas tentang kurikulum dalam dunia pendidikan tentu akan membahas bagaimana impelementasinya dalam pendidikan di sekolah, tentu jawabannya adalah proses pembelajaran, sehingga dalam setiap lembaga pendidikan formal struktur organisasi sekolah yang membahawi bidang ini disebut wakil ketuan bidang kurikulum. Melalui wakil ketua bidang kurikulum diharapkan pelaksanaan kurikulum dapat berjalan dengan baik dan mulai dari penyusunan program pengajaran sampai pada penyusunan laporan pelaksanaan Proses B elajar M engajar secara berkala.

Belajar adalah sebuah proses yang kompleks yang di dalamnya terkandung beberapa aspek. A spek-aspek tersebut adalah bertambahnya jumlah pengetahuan, adanya kemampuan mengingat dan mereproduksi, ada penerapan pengetahuan, menyimpulkan makna, menafsirkan dan mengaitkan dengan realitas, dan adanya perubahan sebagai pribadi11. Bila terjadi

9 Trianto Ibnu Badar Al-Tabany, Mendesain Model Pembelajaran Inovatif, Progresif, Dan Konteksual (Prenada Media, 2017).

10 Desi Rostika and Wildan Zulkarnain, "Analisis Implementasi Kurikulum 2013 Dengan Sistem Kredit Semester," Jurnal Manajemen Pendidikan 25, no. 2 (2016): 191-199.

11 Idi Warsah, "Islamic Psychological Analysis Regarding To Rạ̣mah Based Education Portrait At IAIN Curup," Psikis : Jurnal Psikologi Islami 6, no. 1 (June 1, 2020): 29-41, https://doi.org/10.19109/psikis.v6i1.3941; Idi Warsah and Nuzuar Nuzuar, "Analisis Inovasi Administrasi Guru Dalam Meningkatkan Mutu 
proses belajar maka bersama itu pula terjadi proses mengajar. Hal ini kiranya mudah dipahami, karena bila ada yang belajar sudah barang tentu ada yang mengajarnya, dan begitu pula sebaliknya kalau ada yang mengajar tentu ada yang belajar. Dari proses belajar mengajar ini akan diperoleh suatu hasil, yang pada umumnya disebut hasil belajar. Tetapi agar memperoleh hasil yang optimal, proses belajar mengajar harus dilakukan dengan sadar dan sengaja serta terorganisasi secara baik.

A dapun yang dimaksud dengan belajar menurut Usman dalam Lestari adalah "Perubahan tingkah laku pada diri individu berkat adanya interaksi antara satu individu dengan individu lainnya dan antara individu dengan lingkungan"12. Lebih luas lagi Subrata mendefenisikan belajar adalah "(1) membawa kepada perubahan, (2) Bahwa perubahan itu pada pokoknya adalah didapatkanya kecakapan baru, (3) Bahwa perubahan itu terjadi karena usaha dengan sengaja"13. Dari beberapa defenisi di atas terlihat para ahli menggunakan istilah "perubahan" yang berarti setelah seseorang belajar akan mengalami perubahan.

Salah satu faktor yang mempengaruhi hasil belajar siswa adalah faktor instrumental. Faktor instrumental antara lain gedung atau sarana fisik kelas, sarana atau alat pembelajaran, media pembelajaran, guru, dan kurikulum atau materi pelajaran serta strategi pembelajaran. Tinggi rendahnya hasil belajar peserta didik dipengaruhi banyak faktor-faktor yang ada, baik yang bersifat internal maupun eksternal14. Faktor-faktor

Pembelajaran (Studi Man Rejang Lebong)," Edukasi 16, no. 3 (2018): 294572.

12 Ade Lestari and Muslim Sembiring, "Pengaruh Model Pembelajaran Kooperatif Think Pair Share Terhadap Hasil Belajar PKN oleh Siswa Kelas X SMA Esa Prakarsa Kec. Selesai," Jurnal Serunai Pancasila Dan Kewarganegaraan 9, no. 1 (2020): 21-31.

13 Moch Kabibul Asro and Nailal Muna, "Pengaruh Kompetensi Pedagogik Guru dan Pemanfaatan Media Pembelajaran Terhadap Hasil Belajar Fiqih di MA Darussalam Krempyang Nganjuk," Jurnal Intelektual: Jurnal Pendidikan Dan Studi Keislaman 9, no. 2 (2019): 217-228.

14 Desi Marintan and Widiyanto Widiyanto, "Pengaruh Media Pembelajaran Dan Strategi Belajar Terhadap Hasil Belajar Siswa Kelas X 
tersebut sangat mempengaruhi upaya pencapaian hasil belajar siswadan dapat mendukung terselenggaranya kegiatan proses pembelajaran, sehingga dapat tercapai tujuan pembelajaran.

Kedudukan kurikulum dalam peningkatan hasil belajar siswa itu sanagat berpengaruh dimana jika kurikulum tidak terlaksana dengan baik, maka hasil belajar siswa akan mengalami penurunan. Sebaliknya jika kurikulum berjalan dengan baik dalm sebuah pembelajaran maka akan menigkatkan hasil belajar siswa. Dalam konteks tersebut banyak sekali sekolah yang mengalami kendala dalam menerapkan kurikulum 2013 baik dalam berbagai bidang, salah satunya paling tampak pada hasil belajar siswanya. M inimnya fasilitas serta sarana dan prasarana yang dimiliki menjadi salah satu factor yang menghambat pelaksanaan kurikulum ini tidak maksimal. A pa lagi sekolaoh yang berada di wilayah pelosok misalnya SMA Negeri 3 Rejang Lebong.

\section{$M$ etode Penelitian}

Penelitian ini menggunakan analisis data yang bersifat kualitatif yang disesuaikan dengan tujuan penelitian yaitu berusaha menemukan gambaran implementasi K-13 dan kaitannya dengan peningkatan hasil belajar siswa di SMA Negeri 3 Rejang Lebong. Jika dilihat dari obyek penelitian ini secara purposif ditentukan informan yang akan diminta keterangan lebih dalam dan akurat antara lain, kepala sekolah, waka bidang kurikulum dan guru ${ }^{15}$.

Data dikumpulkan melalui observasi dan wawancara untuk menemukan informasi yang tepat untuk menjawab penelitian ini ${ }^{16}$. Teknik lain yang tidak kalah penting adalah

pada Mata Pelajaran Ekonomi SMA Sedes Sapientiae Semarang (Studi Pada Tahun Ajaran 2015/2016)," Economic Education Analysis Journal 6, no. 1 (2017): 161-172.

15 Chaedar Alwasilah, "Pokoknya Kualitatif: Dasar-Dasar Rancangan Dan Melakukan Penelitian Kualitatif,” Jakarta: Pustaka, 2011.

16 Karen Jiggins Colorafi and Bronwynne Evans, "Qualitative Descriptive Methods in Health Science Research," HERD: Health Environments Research \& Design Journal 9, no. 4 (2016): 16-25; Kathryn Roulston, "Analysing Interviews," The SAGE Handbook of Qualitative Data Analysis, 2014, 297-312; Johnny Saldaña, The Coding Manual for Qualitative Researchers (Sage, 2015). 
dokumentasi untuk melihat gambaran data muatan kurikulum pada dokumen sekolah seperti RPP, Silabus, dokumen guru, prota, promes, Kaldik dalam proses pembelajaran. Setelah data terkumpul dilakukan pemilihan data untuk disajikan dalam hasil penelitian dan dianalisis dalam pembahasan selanjutnya diperoleh simpulan sebagai jawaban permasalahan tentang problematika pelaksanaaan kurikulum K-13 terhadap hasil belajar siswa di SM A Negeri 3 Rejang L ebong ${ }^{17}$.

\section{PEMBAHASAN}

Paparan hasil penelitian yang didapatkan dilapangan tentang problematika pelaksaanaan kurikulum 13 terhadap hasil belajar siswa di SMA Negeri 3 Rejang Lebong terdiri dari beberapa aspek yaitu :1) strategi guru dalam megimplementasikan kurikulum (K-13) guna untuk meningkatkan kualitas hasil belajar siswa di SMA Negeri 3 Rejang Lebong 2) faktor- factor pendukung dan penghambat implementasi kurikulum 2013 dalam peningkatan hasil belajar siswa di SM A Negeri 3 Rejang Lebong.

Strategi guru dalam megimplementasikan kurikulum 13 guna untuk meningkatkan kualitas hasil belajar siswa di SM A Negeri 3 Rejang Lebong.

Berdasarkan hasil observasi dan wawancara di SMA Negeri 3 Rejang Lebong bahwa strategi guru dalam melaksanakan kurikulum 2013 (K-13) masih banyak perlu ditingkatkan lagi serta dianalisis dalam proses pelaksanaan kegiatan belajara mengajar apalag didalam kurikulum 2013 (K 13) ini lebih banyak melaksanaan kegiatan praktek dan lebih sedikit teori.

Bapak Wardoyo S.Pd selaku kepala sekolah di SMA Negeri 3 Rejang Lebong juga mengatakan bahwa

"Dalam kegiatan belajar mengajar banyak guru yang belum mendapat buku pegangan masing-masing untuk mengajar, hal ini membuat guru-guru terbatas dalam hal memahami materi yang diajarkan. Padahal implementasi

${ }^{17}$ Matthew B. Miles, M. A. Huberman, and J. Saldana, "Qualitative Analysis: An Expanded Sourcebook,” Thousand Oaks, CA: Sage, 1994. 
kurikulum K-13 diharapkan dapat menghasilkan insan yang produktif, kreatif dan inovatif". Lebih lanjut beliau mengatakan "karena kurikulum ini berbasis karakter dan kompetensi, yang secara konseptual memiliki beberapa keunggulan. Kurikulum K-13 menggunakan pendekatan yang bersifat alamiah (kontekstual), karena berangkat, berfokus, dan bermuara pada hakekat peserta didik untuk mengembangkan berbagai kompetensi sesuai dengan potensinya masing-masing" 18 .

Pendapat bapak Wardoyo di atas memperjelas bahwa dalam K -13 peserta didik merupakan subjek belajar, dan proses belajar berlangsung secara alamiah dalam bentuk bekerja dan mengalami berdasarkan kompetensi tertentu, bukan transfer pengetahuan (transfer of knowledge). Sementara tujuan, strategi fungsional, pengaturan struktural, dan faktor-faktor manusia sangat penting diperhatikan dalam implementasi kurikulum K -13. A rtinya implementasi kurikulum yang efektif merupakan hasil dari interaksi antara strategi implementasi, struktur kurikulum, tujuan pendidikan, sisitem, profesionalitas guru, kompetensi tenaga kependidikan, dan kepemimpinan kepala sekolah. Oleh karena itu, untuk mengoptimalkan implementasi kurikulum K-13 diperlukan suatu upaya strategis untuk mensinergikan komponen-komponen tersebut, terutama guru dan kepala sekolah dalam membudayakan kurikulum.

M emperkuat pendapat bapak kepala sekjolah di atas, ibu Sri S.Pd selaku salah satu guru PA I mengatakan bahwa

"M inimnya sarana dan prasarana di SMA Negeri 3 Rejang Lebong menyebabkan sulitnya guru untuk melaksanakan kegiatan praktek mengingat dikurikulum 2013 ini banyak kegiatan praktek. Untuk memperoleh hasil belajar, diperlukan penilaian atau dilakukan evaluasi pada siswa atau terdidik yang merupakan tindak lanjut atau cara yang dilakukan untuk mengukur tingkat penguasaan siswa atau terdidik dalam proses belajar mengajar yang sesuai dengan tujuan pengajaran.

${ }^{18}$ Wawancara, 16 Februari 2020 
Bahkan hasil belajar juga dipengaruhi oleh motivasi guru dan metode pembelajaran yang memadai ${ }^{19}$.

Selain itu ibu Dwi Wahyuni S.Pd menyatakan bahwa "Pelaksaanaan kurikulum K-13 di sekolah ini dilaksanaakan sejak beberapa tahun lalu, termasuk ada beberapa kendala dalam menerapkannya seperti, sarana dan prasarana yang hingga saat sekarang ini belum memadai sepenuhnya. Namun, walalupun terkendala hal tersebut sekolah ini tidak hentinya memaksimalkan pelaksanaan kurikulum K -13 dengan baik agar siswa maupun siswi mendapatkan ilmu yang sesuai dengan sekolah lainnya ${ }^{20}$. Dengan demikian, pelaksanaan kurikulum K 13 dilaksanakan dengan semaksimal mungkin walaupun keterbatasan fasilitas.

Berdasarkan informasi di atas dapat disimpulkan bahwa pelaksanaan kurikulum K-13 sudah berjalan sebagai mana mestinya, hal ini diperkuat oleh hasil wawancara kepada siswa kelas XI "bahwa pelaksanaan kurikulum K -13 ini sudah cukup efektif hal ini didorong oleh cara mengajar guru yang baik dan siswa pun bisa menerima materi dengan baik juga"21. Data adanya observasi langsung ditemukan dibeberapa kelas yang terlihat bahwa guru yang mengajar cukup baik dala menyampaikan materi dan menerapkan banyak variasi dalam kegiatan belajar mengajar22. Hal ini membuktikan bahwa strategi guru dalam melaksanakan kurikulum K-13 sudah berjalan cukup efektif walaupun keterbatasan fasilitas.

Berdasarkan data observasi menunjukkan inovasi guru terlihat di sekolah dalam upaya melaksanakan kurikulum K -13 ini, melihat beberapa kelas yang sedang melakukan kegiatan belajar mengajar peneliti menemukan kelas yang sangat aktif, fokus dan sangat memperhatikan guru yang mengajar di depan. Mengenai hal tersebut Ibu Nur S,Pd menyatakan bahwa: "sekolah ini memang kurang sarana dan prasarananya tapi hal tersebut tidak menjadi penghambat kami sebagai guru untuk menerapkan strategi mengajar yang sevariatif mungkin agar

\footnotetext{
${ }^{19}$ Wawancara, 18 Februari 2020

${ }^{20}$ wawancara 20 February 2020

${ }^{21}$ Wawancara 20 Februari 2020

${ }^{22}$ Observasi 20 Februari 2020
} 
peserta didik bias semaksimal mungkin mengikuti pelajaran dan bias menangkap materi yang kami ajaran"23. Hal ini menjelaskan bahwa sebagai guru yang profesional sudah seharusnya menujukkan keprofesionalitasannya dengan hal tersebut.

Pendapat di atas dibenarkan oleh Bapak Wardoyo S.Pd selaku kepala sekolah yang menyatakan bahwa:

"Guru harus memiliki kompetensi salah satunya profesionalitas, begitupun guru di sekolah ini dalam rangka menunjang keberhasilan pelaksanaan kurikulum 2013 ini meskipun banyak hal yang menjadi penghambat ketidak berhasilannya, guru disekola ini semaksimal mungkin memberikan pelayananyang baik dengan cara menerapkan strategi mengajar yang baik pula, yang baik maksudnya yang mudah dipahami peserta didik dan mampu diterima peserta didik. Baik dari strategi, metode maupun materi yang diajarkan harus benar-benar matang dan sudah dimengerti dengan sangat baik oleh para guru" 24 .

Berpijak dari paparan di atas disimpulkan bahwa strategi guru dalam mengimplementasikan kurikulum 2013 guna untuk meningkatkan kualiatas hasil belajar siswa sudah cukup inovatif dan efektif, baik dilihat dari data observasi diatas maupun hasil wawancara. Dalam pembelajaran kurikulum sangat berpengaruh dalam hal komponen pembelajaran yang akan dilakukan, hal inilah yang menjadi acuan guru untuk mengajar secara kreatif sesuai kurikulum yang digunakan, bila guru berhasil menerapkan kurikulum dalam pembelajaran secara baik maka, hasil belajar siswa akan baik juga.

Faktor-factor pendukung dan penghambat implementasi kurikulum 13 dalam peningkatan hasil belajar siswa di SMA Negeri 3 Rejang Lebong.

K epala Sekolah dan para guru merupakan para pendidik dalam dunia pendidikan yang mempunyai tugas dan tanggung

\footnotetext{
${ }^{23}$ Wawancara 19 February 2020

${ }^{24}$ Wawancara 19 February 2020
} 
jawab mengelolah pendidikan. Di samping itu kepala sekolah dan para guru dituntut untuk mewujudkan tujuan pendidikan sesuai dengan visi dan misi yang ada di sekolah termasuk pelaksanaan kurikulum 13 meskipun tidak mudah dilakukan. Berdasarkan hasil penelusuran di lapangan ditemukan faktorfaktor pendukung dan penghambat implementasi kurikulum 13 dalam peningkatan hasil belajar siswa di SM A Negeri 3 Rejang Lebong, peneliti mencoba mewawancarai kepala sekolah dan beliau menjelaskan bahwa: "dalam melaksanakan kurikulum 13 ini terdapat banyak sekali factor penghambat dan pendukung dalam peningkatan hasil belajar siswa baik dari segi internal maupun eksternal"25.

Data hasil observasi menunjukkan bahwa para guru yang terkait untuk mengetahui pernyataan di atas mengenai faktor pendukung dan penghambat pelaksanaan kurikulum 2013 ini, ibu M utia A yu, S. Pd, bahwa memang peran kepala sekolah sangat membantu karena sering memberikan evaluasi tentang pelaksanaan kurikulum di sekolah ini, memberikan arahan yang baik maupun buruk unruk menunjang keefektifan guru dalam melaksanakan kurikulum 13 ini26. Jika dilihat dari pernyaataan guru terkait bahwa memang benar pernyataan yang disampaikan oleh kepala sekolah mengenai hal tersebut, dengan adanya sistem seperti itu maka para guru akan mengubah cara mengajar emereka apabila tidak sesuai dengan standard semestinya.

Kemudian untuk memastikan kembali pernyataan tersebut peneliti kembali mewawancarai guru yang terkait dengan pelaksanaan kurikulum 13 ini, peneliti langsung mewawancarai guru Pendidikan A gama Islam di SM A N egeri 3 Rejang Lebong, ibu Sri, S.Pd yang berpendapat bahwa Faktor pendorong pengembangan K urikulum 13 ada dua yaitu:

"T antangan internal dan tantangan eksternal, Tantangan internal antara lain terkait dengan kondisi pendidikan dikaitkan dengan tuntutan pendidikan yang mengacu kepada 8 (delapan) Standar Nasional Pendidikan yang

\footnotetext{
${ }^{25}$ Wawancara 7 Februari 2020

${ }^{26}$ Observasi dan Wawancara 15 Februari 2020
} 
meliputi standar isi, standar proses, standar kompetensi lulusan, standar pendidik dan tenaga kependidikan, standar sarana dan prasarana, standar pengelolaan, standar pembiayaan, dan standar penilaian pendidikan. Tantangan internal lainnya terkait dengan perkembangan penduduk Indonesia dilihat dari pertumbuhan penduduk usiaproduktif. Tantangan eksternal antara lain terkait dengan arus globalisasi dan berbagai isu yang terkait dengan masalah lingkungan hidup, kemajuan teknologi dan informasi, kebangkitan industri kreatif dan budaya, dan perkembangan pendidikan di tingkat internasional" 27 .

Terkait dengan semua itu minat belajar peserta didik terhadap pelaksanaan kurikulum 13 disekolah ini, maka hasil wawancara dengan salah satu guru yaitu Bapak Erwan S.Pd menyatakan bahwa: "membangkitkan minat belajar peserta didik dengan menerapkan cara mengajar yang kreatif dan inovatif dengan menggunakan media pembelajaran yang semenarik mungkin agar minat belajar peserta didik muncul dengan sendirinya" 28 .

Menurut pendapat di atas diperkuat dengan argument dari salah satu guru yaitu ibu Susi S.Pd yang menyatakan bahwa fator pendukung pelaksanaan kurikulum terhadap peningkatan hasil belajar siswa ada dua yaitu faktor fisiologis dan faktor pskikologis29. Secara umum kondisi fisiologis dimaksud oleh guru tersebut seperti kesehatan yang prima, tidak dalam keadaan lelah dan capek, tidak dalam keadaan cacat jasmani dan sebagainya. $\mathrm{Hal}$ tersebut dapat mempengaruhi peserta didik dalam menerima materi pelajaran. Sementara factor psikologis seperti intelegensi (IQ), perhatian, minat, bakat, motif, motivasi, kognitif dan daya nalar peserta didik. Informasi ini dapat diambil kesimpulan bahwa faktor pendukungnya berasal diri siswa itu sendiri.

Jadi beberapa argumentasi diatas menggambarkan bahwa factor-faktor pendukung pelaksanaan kurikulum 13 ini

\footnotetext{
${ }^{27}$ Wawancara 15 february 2020

${ }^{28}$ Wawancara 5 maret 2020

${ }^{29}$ Wawancara 6 Maret 2020
} 
bisa berasal dari dalam (internal) dan dari luar(eksternal), yang dimana factor-faktor tersebut sangat mendukung keberhasilan dalam melaksanakan kurikulum 13 dengan baik. A sumsi ini diperkuat lagi dengan hasil observasi siswa yang sedang dalam kegiatan belajar mengajar, dimana interaksi antara siswa dan guru yang berjalan dengan baik dikarenakan variasi-variasi metode yang digunakan guru tersebut sangat efektif dalam pembelajaran.

Selain itu pendapat dari salah satu guru yaitu ibu Citra, S.Pd yang menyatakan bahwa "faktor penghambat pelaksanaan kurikulum terdapat beberapa indicator baik secara internal maupun eksternal, dalam mengatasi faktor penghambat tersebut dibutuhkan kerjasama guru serta kemampuan mengolah serta menguasai materi dengan baik yang akan tetap melaksanakan kegiatan belajar mengajar yang efektif" 30 .

M emperkuat di atas dari data hasil observasi didapatkan bahwa ketika dalam proses kegiatan belajar mengajar dikelas, dilihat bahwa gurunya memaksimalkan penggunaan media pembelajaran walaupun sangat terbatas, guru memberikan kesempatan kepada para peserta didik untuk berkreatifitas dengan membagi kelompok dan setiap kelompok diberiakan tugasnya masing-masing. Dengan adanya metode seperti ini, maka para peserta didik mampu mengembangkan kreatifitasnya masing-masing dan memberikan mereka waktu untuk berdiskusi agar masing-masing kelompok mendapatkan informasi materi dari kelompoknya masing-masing denan cara berkreasi sambil belajar. Y aitu hanya dengan cara menggunakan media karton, kertas dan pensil warna saja31.

Berdasarkan paparan di atas, didapatkan bahwa antara beberapa factor penghambat diatas terdapat beberapa solusi yang sudah disiapkan oleh para guru dalam meminimalisir terjadinya ketidakefektifan dalam melaksanakan Kurikulum 13 ini, dalam suatu konteks memang segala sesuatunya memiliki factor penghambat baik hal ini sangat berpengaruh maupun tidak banyak berpengaruh terhadap pelaksanaannya, oleh

\footnotetext{
${ }^{30}$ Wawancara 6 maret 2020

${ }^{31}$ Wawancara 6 maret 2020
} 
karena itu untuk mengimbangi hal tersebut para guru harus berusaha untuk selalu kreatif dan inovatif dalam mengimplementasikannya baik dalam kegiatan belajar mengajar maupun diluar kelas.

Selain itu bapak Wardoyo S.Pd selaku kepala sekolah menyatakan bahwa: "D alam proses belajar mengajar baik K TSP maupun Kurikulum 2013 keduanya harus ada rancangan mengenai masing-masing sistem belajar, selain itu pasti ada factor-faktor pendukung maupun penghambatnya, tinggal bagaimana kita sebagai seorang guru harus bisa menjalankannya dengan sebaik mungkin meskipun banyak kendala yang dihadapi"32. Informasi ini disimpulkan bahwa sekolah ini sangat memaksimalkan pelaksanaan kurikulum 2013 dengan baik.

B erdasarkan data observasi juga didapat bahwa adanya faktor pendukung dan penghambat pelaksanaan kurikulum 13 bisa menjadi penentu suatu keberhasilan dari pelaksanaan itu sendiri. Selain itu bapak Erwan S,Pd kembali memmberikan argument nya yang menyatakan bahwa: "banyak sekali factor yang menghambat keefektifan dalam melaksakan kurikulum 13 ini salah satunya yaitu sarana dan prasarananya, akibatnya banyak siswa yang tidak terlalu serius dalam menanggapi pelajaran banyak siswa yang kurang memperhatikan bahkan keluar masuk kelas karena minat belajarnya yang kurang dan hal ini mengakibatkan penurunan hasil belajar yang didapat siswa"33.

Melihat dari asumsi di atas, berdasarkan data yang diperoleh dari observasi lapangan dan melihat dokumentasi guru dilihat nilai siswa yang mengalami penurunan dan banyak yang remedial dikarenakan siswanya tidak mengerti tentang materi tersebut. Hasil dari wawancara dengan salah satu siswa kelas XI mengeni hasil belajar inipun memperkuat argument di atas, ia mengatakan bahwa "penyebab terjadinya penurunan hasil belajar itu adalah pelajaran yang membosankan dan banyaknya praktek dalm pelajaran dan fasilitas untuk

\footnotetext{
${ }^{32}$ Wawancara 6 Maret 2020

${ }^{33}$ Wawancara 6 Maret 2020
} 
prakteknya pun kurang memadai akibatnya, semangat belajar siswa tidak begitu muncul" 34 . Berdasarkan informasi di atas disimpulkan bahwa faktor penghambat pelaksanaan kurikulum ini sangat berpengaruh terhadap peningkatan hasil belajar siswa.

Paparan data di atas terlihat jelas bahwa seorang guru harus memiliki kemampuan untuk menumbuhkan semangat belajar siswa dalam hal untuk mendapatkan hasil belajar yang semaksimal mungkin. Sehingga pembelajaran juga menjadi lebih bermakna. Untuk menciptakan hal tersebut sangat diperlukan guru yang kreatif, inovatif dan cerdas dalam mengembangkan strategi untuk melaksanakan kurikulum 2013 ini dengan baik, dengan guru yang profesional maka guru tersebut akan mengerti pentingnya keberhasilan peserta didik meningkatkan hasil belajarnya dan dengan hal tersebut juga peserta didik akan menjadi terdorong dan lebih bersemnagat belajar sehingga tercipta kegiatan belajar yang tidak membosankan, dinamis dan nyaman dalm kegiatan belajar mengajar.

Dalam pembelajaran yang baik juga harus didukung dengan media yang memadai juga dimana itu adalah salah satu faktor yang mendukung kegiatan pembelajaran berjalan dengan baik, apalagi seperti yang kita ketahui bahwa di dalam kurikulum 13 itu lebih banyak praktek daripada teori, disetiap teoripun pasti ada praktek. Hal tersebut tentunya membahas mengenai fasilitas dan sarana prasarana, itula mengapa didalam pembelajaran dibutuhkan sarana dan prasarana yang baik juga untuk menunjang hasil belajar siswa.

Berdasarkan dari hasil observasi dan wawancara diatas dipeoleh jawaban dari Faktor-factor pendukung dan penghambat implementasi kurikulum 2013 dalam peningkatan hasil belajar siswa di SMA Negeri 3 Rejang Lebong. Indicator yang menjadi simpulan adalah : tantangan internal dan tantangan eksternal, Tantangan internal antara lain terkait dengan kondisi pendidikan dikaitkan dengan tuntutan pendidikan yang mengacu kepada 8 (delapan) Standar Nasional

${ }^{34}$ Wawancara 6 maret 2020 
Pendidikan yang meliputi standar isi, standar proses, standar kompetensi lulusan, standar pendidik dan tenaga kependidikan, standar sarana dan prasarana, standar pengelolaan, standar pembiayaan, dan standar penilaian pendidikan. Tantangan internal lainnya terkait dengan perkembangan penduduk Indonesia dilihat dari pertumbuhan penduduk usiaproduktif. Tantangan eksternal antara lain terkait dengan arus globalisasi dan berbagai isu yang terkait dengan masalah lingkungan hidup, kemajuan teknologi dan informasi, kebangkitan industri kreatif dan budaya, dan perkembangan pendidikan di tingkat internasional.

\section{KESIMPULAN}

Pelaksanaan kurikulum 2013 terhadap hasil belajar siswa di SMA Negeri 3 Rejang Lebong dipandang sudah berjalan dengan baik meskipun ada beberapa kendala yang dihadapi terutama fasilitas pembelajaran. Kendala tersebut dapat diatasi berkat sinergitas pimpinan sekolah dengan guru yang berkomitmen melaksanakan amanah undang-undang sistem pendidikan nasional yaitu penerapan K-13 dengan menggunakan berbagai strategi dan kemampuan yang dimiliki oleh sekolah, seperti pelatihan kompetensi guru, melaksanakan kewajiban membuat perencanaan pembelajaran dalam bentuk RPP dan silabus, memberikan laporan bulanan tentang pelaksanaan pembelajaran oleh guru dan melakukan evaluasi serta pembinaan terhadap kinerja guru. A danya peran seluruh guru dan siswa yang ikut andil dalam mensukseskan pelaksanaan kurikulum inipun juga menjadi faktor utama tercapainya keinginian yang diharapkan, adanya minat belajar siswa dan guru yang kreatif menjadikan pelaksanaan disekolah ini berjalan dengan efektif. 


\section{DAFTAR PUSTAKA}

Adnan, M ohammad. "Evaluasi Kurikulum Sebagai Kerangka A cuan Pengembangan Pendidikan Islam." Al-/daroh: Jurnal Studi Manajemen Pendidikan Islam 1, no. 2 (2017): 108-29.

Alhaddad, Muhammad Roihan. "Hakikat Kurikulum Pendidikan Islam." Raudhah Proud To Be Professionals: Jurnal Tarbiyah Islamiyah 3, no. 1 (2018): 57-66.

Al-Tabany, Trianto Ibnu Badar. Mendesain Model Pembelajaran Inovatif, Progresif, Dan Konteksual. Prenada M edia, 2017.

Alwasilah, Chaedar. "Pokoknya Kualitatif: Dasar-Dasar Rancangan Dan Melakukan Penelitian Kualitatif." Jakarta: Pustaka, 2011.

A rifin, Zainul, Saida Ulfa, and Henry Praherdhiono. "Pengembangan Kurikulum Muatan Lokal Karawitan Sebagai Upaya Mengkonstruksi Pengetahuan dan Pelestarian Budaya Jawa Di Jenjang SMA." Jurnal Kajian Teknologi Pendidikan 1, no. 2 (2018): 123-132.

A sro, Moch Kabibul, and Nailal M una. "Pengaruh Kompetensi Pedagogik Guru Dan Pemanfaatan M edia Pembelajaran Terhadap Hasil Belajar Fiqih Di MA Darussalam K rempyang Nganjuk." Jurnal Intelektual: Jurnal Pendidikan Dan Studi Keislaman 9, no. 2 (2019): 217228.

Colorafi, Karen Jiggins, and Bronwynne Evans. "Qualitative Descriptive Methods in Health Science Research." HERD: Health Environments Research \& Design Journal 9, no. 4 (2016): 16-25.

Fadlillah, Muhammad. "Model Kurikulum Pendidikan Multikultural di Taman Kanak-Kanak." Jurnal 
Pembangunan Pendidikan: Fondasi Dan A plikasi 5, no. 1 (2017): 42-51.

Fawaz, Fawaz. "Filsafat Pendidikan Islam, Tinjauan Filosofis Tentang Kurikulum." Jurnal Al-Irfani: Jurnal Kajian Tafsir Hadits 5, no. 2 (2019): 1-14.

Herbimo, Widiatmoko. "K urikulum Bukan Senjata Pamungkas K eberhasilan Pendidikan." Jurnal IImiah WUNY 18, no. 2 (2016).

Irmadani, Indah Sari. "Implementasi K urikulum 2013 Mata Pelajaran Pendidikan A gama Islam Di SD Swasta (Studi Kasus Pada Sekolah Dasar Swasta Islam Terpadu Permata Cendekia)." ANSIRU PAl: Pengembangan Profesi Guru Pendidikan Agama Islam 3, no. 1 (2019): 46-61.

Islam, Syaiful. "K arakteristik Pendidikan Karakter; M enjawab Tantangan Multidimensional Melalui Implementasi Kurikulum 2013." Edureligia: Jurnal Pendidikan A gama Islam 1, no. 1 (2017): 89-100.

Lestari, Ade, and Muslim Sembiring. "Pengaruh Model Pembelajaran Kooperatif Think Pair Share terhadap Hasil Belajar PKN Oleh Siswa Kelas X SMA Esa Prakarsa Kec. Selesai." Jurnal Serunai Pancasila Dan Kewarganegaraan 9, no. 1 (2020): 21-31.

Lionar, Uun, and Agus Mulyana. "Nilai-Nilai Multikultural Dalam Pembelajaran Sejarah: Identifikasi Pada Silabus." Indonesian Journal of Social Science Education (IJSSE) 1, no. 1 (2019): 11-25.

Marintan, Desi, and Widiyanto Widiyanto. "Pengaruh Media Pembelajaran dan Strategi Belajar terhadap Hasil Belajar Siswa Kelas X Pada Mata Pelajaran Ekonomi Sma Sedes Sapientiae Semarang (Studi Pada Tahun 
Ajaran 2015/2016)." Economic Education Analysis Journal 6, no. 1 (2017): 161-172.

Ma'rufah, Afni. "Implementasi Kurikulum Mata Pelajaran Pendidikan A gama Islam (U paya M ewujudkan Budaya Religius Di Sekolah)." Edukasia: Jurnal Pendidikan dan Pembelajaran 1, no. 1 (2020): 125-136.

Miles, Matthew B., M. A. Huberman, and J. Saldana. "Qualitative Analysis: An Expanded Sourcebook." Thousand Oaks, CA : Sage, 1994.

Nasbi, Ibrahim. "Manajemen Kurikulum: Sebuah Kajian Teoritis." Idaarah: Jurnal Manajemen Pendidikan 1, no. 2 (2017).

Nur, Syahabuddin. "Peran dan Kontribusi Penerjemahan Pada M ata Pelajaran B ahasa A rab Tingkat M adrasah A liyah." A / Mi'yar: Jurnal IImiah Pembelajaran Bahasa A rab Dan Kebahasaaraban 2, no. 1 (2019): 105-126.

Prastowo, A ndi. M enyusun Rencana Pelaksanaan Pembelajaran (RPP) Tematik Terpadu: Implementasi Kurikulum 2018 Untuk SD/M I. K encana, 2017.

Rijal, Fakhrul. "Guru Profesional Dalam Konsep Kurikulum 2013." Jurnal mudarrisuna: Media Kajian Pendidikan A gama Islam 8, no. 2 (2018): 328-346.

Rostika, Desi, and Wildan Zulkarnain. "A nalisis Implementasi Kurikulum 2013 Dengan Sistem Kredit Semester." Jurnal Manajemen Pendidikan 25, no. 2 (2016): 191199.

Roulston, Kathryn. "A nalysing Interviews." The SAGE Handbook of Qualitative Data A nalysis, 2014, 297-312.

Saldaña, Johnny. The Coding Manual for Qualitative Researchers. Sage, 2015. 
Sunengsih, Neneng. "A nalisis Kebijakan Standar Kompetensi Lulusan Dan Standar Isi Pendidikan Agama Islam Dalam Kurikulum Nasional." AI Ulya: Jurnal Pendidikan Islam 5, no. 1 (2020): https-doi.

Talibo, Ishak. "Fungsi Manajemen Dalam Perencanaan Pembelajaran." Jurnal I/miah Iqra' 7, no. 1 (2018).

Warsah, Idi. "Islamic Psychological A nalysis Regarding To Rahmah Based Education Portrait At IAIN Curup." Psikis: Jurnal Psikologi Islami 6, no. 1 (J une 1, 2020): 29-41. https://doi.org/10.19109/psikis.v6i1.3941.

Warsah, Idi, and Nuzuar Nuzuar. "A nalisis Inovasi Administrasi Guru Dalam Meningkatkan Mutu Pembelajaran (Studi M an Rejang Lebong)." Edukasi 16, no. 3 (2018): 294572.

Y asykur, M och. "Implementasi Kurikulum 2013 Di Madrasah Aliayah Ibnu Taimiyah Bogor." Edukasi Islami: Jurnal Pendidikan Islam 3, no. 05 (2017). 